\title{
オレフィンの接触ハイドロアルミネーション を経由する合成反応
}

\author{
佐 藤 史 衛*
Organic Syntheses via Hydroalumination of Olefins Catalyzed by Titanium or Zirconium Compounds.

Fumie S Ato*

\begin{abstract}
The recently developed hydroalumination reaction of olefins catalyzed by titanium or zirconium compounds makes many organoaluminum compounds readily available and investigation up to now revealed that this new hydroalumination reaction is useful in syntheses starting from olefins.

The present article reviews organic synthesis via hydroalumination which includes introduction of functional groups to the terminal carbon and lengthening the carbon chain of olefins.
\end{abstract}

\section{1. はじめに}

石油化学により多くの種類のオレフィン類が容易に得 られ，そのらえ，それらオレフィン類のオリゴメリゼー ションやテロメリゼーションによってさらに多種多様の オレフィン類の合成が可能になっている現在，これらオ レフィン類をファインケミストリー原料として利用する 方法を開拓することはきわめて重要な課題である。

そのひとつの有力なアプローチとして金属水素化物の オレフィンの付加反応（ハイドロメタレーション）によ って得られる有機金属化合物を有機合成に利用する方法 がある。

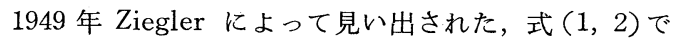
示されるアルミニウム水素化物のオレフィンへの付加反 応 (ハイドロアルミネーション反応, HA反応と略称) はオレフィンから值接アルキルアルミニウム化合物を合 成することを可能にしただけでなく，Ziegler 触媒の発 見にまで続く有袎アルミニウムの新しい化学の始まりと なった重要な発見であった1)。しかし 1956 年 Brownに よって見い出されたハイドロボレーション反応 ${ }^{2)}$ (式(3), $\mathrm{HB}$ 反応と省略）がオレフィン類を出発原料とする実験

* 東京工業大学工学部化学工学科 Department

* Department of Chemical Engineering, Faculty of Engineering, Tokyo Institute of Technology
室的合成手段として大きく発展したのと比較すると ${ }^{3)}$, 式 $(1,2)$ の反応はかなり㛜しい反応条件を必要とする ため，ほとんど有機合成の手段としては用いられてこな かった。

HA 反応

$$
\begin{aligned}
& \mathrm{AlH}_{3}+3 \mathrm{RCH}=\mathrm{CH}_{2} \rightarrow \mathrm{Al}\left(\mathrm{CH}_{2} \mathrm{CH}_{2} \mathrm{R}\right)_{3}(1) \\
& \mathrm{LiAlH}+4 \mathrm{RCH}=\mathrm{CH}_{2} \rightarrow \operatorname{LiAl}\left(\mathrm{CH}_{2} \mathrm{CH}_{2} \mathrm{R}\right)_{4}
\end{aligned}
$$

HB 反応

$$
\mathrm{BH}_{3}+3 \mathrm{RCH}=\mathrm{CH}_{2} \rightarrow \mathrm{B}\left(\mathrm{CH}_{2} \mathrm{CH}_{2} \mathrm{R}\right)_{3}
$$

最近著者らはチタンあるいはジルコニウム化合物を触 媒とすると, 式 $(1,2)$ の反応が室温ですみやかに進行 することを見い出した ${ }^{4 \sim 6)}$ ，この発見により HA 反応が HB 反応と同㥞, 実験室的合成手段として利用できるよ らになった。

この接触 HA反応に関しては, すでに触媒の面から解 説したので7,8)，本稿では HA反応の有機合成への応用 についてHB法と比較しつつまとめてみたい。

なおオレフィン類のHAに比較して温和な条件下，位 置および立体選択性高く進行するアセチレン類の $i-\mathrm{Bu}_{2}$ $\mathrm{AlH}$ を用いる HA 反応はすでに実験室的合成反応とし て高い評価を得ている。それに関しては総説を参照され たい9,10)。

\section{2. 接触 HA 反応の特徴}

接触 HA 反応が見い出されるまでの経緯および反応機 
Table 1 Scope of the Hydroalumination reaction.

\begin{tabular}{l|l|l|l}
\hline \multicolumn{1}{c|}{ Olefin } & \multicolumn{1}{c|}{ Solvent } & \multicolumn{1}{c}{ Catalyst } & \multicolumn{1}{c}{ Aluminum hydride } \\
\hline \multirow{2}{*}{ 1-Olefin } & Ether & $\mathrm{Cp}_{2} \mathrm{TiCl}_{2}$ & $\mathrm{LiAlH}_{4}$ \\
\cline { 2 - 4 } & $\begin{array}{l}\mathrm{THF} \\
\mathrm{TiCl}\end{array} \mathrm{ZrCl}_{4}$, \\
& \multirow{2}{*}{$\begin{array}{l}\mathrm{Cp}_{2} \mathrm{TiCl}_{2}, \mathrm{Cp}_{2} \mathrm{ZrCl}_{2} \\
\mathrm{TiCl}_{4}-\mathrm{AlEt}_{3}\end{array}$} & $\begin{array}{l}\mathrm{LiAlH}_{4}, \mathrm{AlH}{ }_{3}, \mathrm{AlH}{ }_{2} \mathrm{Cl}, \\
\mathrm{AlCl}_{2}\end{array}$ \\
\cline { 3 - 4 } & & $\mathrm{Cp}_{2} \mathrm{TiCl}_{2}$ & $\mathrm{LiAlH}_{n}(\mathrm{OR})_{4-n}(n=1 \sim 3)$ \\
\hline Internal olefin & Diglyme & $\mathrm{TiCl}_{4}$ & $\mathrm{LiAlH}_{4}$ \\
\hline $\begin{array}{l}\text { Allyl alcohol } \\
\text { Allyl ether }\end{array}$ & THF & $\mathrm{ZrCl}_{4}, \mathrm{Cp}_{2} \mathrm{ZrCl}_{2}$ & $\mathrm{LiAlH}_{4}$ \\
\hline
\end{tabular}

構についてはすでに解説した ${ }^{7,8)}$ ，ここでは有機合成手 段として利用するのに必要な知っておいてもらいたい HA 反応の特徵について簡単に述べる。

2.1. 反応の方法 反応はオレフィンとアルミニウ ム水素化物のエーテル系溶液へ触媒量のチタンあるいは ジルコニウム化合物を加えることにより室温で容易に進 行する。

ただし, 反応の成否はオレフィン, 触媒, 溶媒そして アルミニウム水素化物の組合わせに依存していて, 表 1 に示す組合わせで行うとよい結果が得られる。

試薬の加える順序も注意する必要がある。著者らと同 時に $\mathrm{Cp}_{2} \mathrm{TiCl}_{2}$ がオレフィンと $\mathrm{LiAlH}_{4}$ の付加反応の触 媒となることを見い出した大辻らは, 初めに $\mathrm{C}_{2} \mathrm{TiCl}_{2}$ と $\mathrm{LiAlH}_{4}$ を反応させ触媒活性種を作り, その後オレフ ィンを加え $\mathrm{LiAlH}_{4}$ と反応させるといった方法をとった ため, 反応は 1 当量ないしは 2 当量のオレフィンが挿入 した段階で停止してしまい, 残っているオレフィンは異 性化してしまうこと, さらに適用できるオレフィンも2位に置換基をもたない1-オレフィンに限られるという結 果を得ている ${ }^{11,12)}$ (式 4 )。

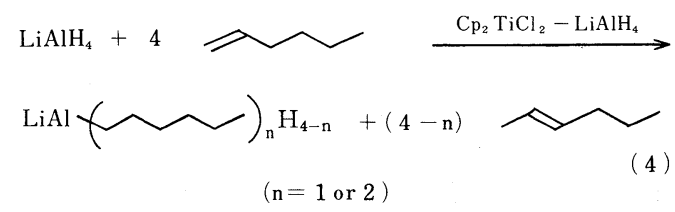

このように試薬の加える順序, いいかえれば触媒の熟 成の仕方，により異なった結果が得られたことは興味深 い。しかしHA反応を有機合成に応用する場合，大辻ら の系は, 単に適用できるオレフィンの種類が限られるだ けでなく, 残存しているハイドライドが次段階の反応を 複雑化させること, おょびアルミニウム水素化物あたり の有効度が低いという久点をもつ。
生成するアルキルアルミニウム化合物は使用するアル ミニウム水素化物の種類により，3配位のアルキルアラ ン 1 あるいは 4 配位のアルキルアルミナート 2 になるアラ ンとアルミナートの反応性は異なるので合成の目的に応 じてアルミニウム水素化物を選択する必要がある。

$$
\text { alkylalane }
$$<smiles>[R][Al]([X])[X]</smiles>

1

\section{alkylaluminate}

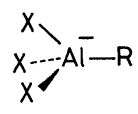

2
市販品として容易に入手できること，またテトラアル キルアルミナートは塩化アルミニウムを作用させて容易 にトリアルキルアルミニウムに変換できること（式５） などを考えると, 実験室的合成の目的にはアルミニウム 水素化物として $\mathrm{LiAlH}_{4}$ を用いると都合がよいと思われ る。

$$
\mathrm{LiAlR}_{4}+\frac{1}{3} \mathrm{AlCl}_{3} \rightarrow \frac{4}{3} \mathrm{AlR}_{3}+\mathrm{LiCl}
$$

2. 2. 反応の位置選択性 HA 反応は表 1 に示した ように条件さえ選べば,かなり幅広いオレフィンに適用で きる。付加の位置選択性についてであるが，末端炭素に $\mathrm{Al}$ が付加した生成物が 1-オレフィンでほぼ $100 \%$, 内 部オレフィンでも約 $85 \%$ の選択性で得られる。この反 応位置選択性高く末端炭素に Al が付加することが HA 反応の大きな特色であり, 後述するようにHA を経由し て得られるハライドやアルコールは反マルコニコフ付加 した生成物となる。

HA の速度はオレフィンの構造に大きく依存していて, オレフィンの種類により速度の大きさは次の順序となる。

$$
\mathrm{RCH}=\mathrm{CH}_{2}>\mathrm{RR}^{\prime} \mathrm{C}=\mathrm{CH}_{2}>\mathrm{RCH}=\mathrm{CHR}^{\prime}
$$

この性質を利用して非共役ポリエンの立体障害の小さ 


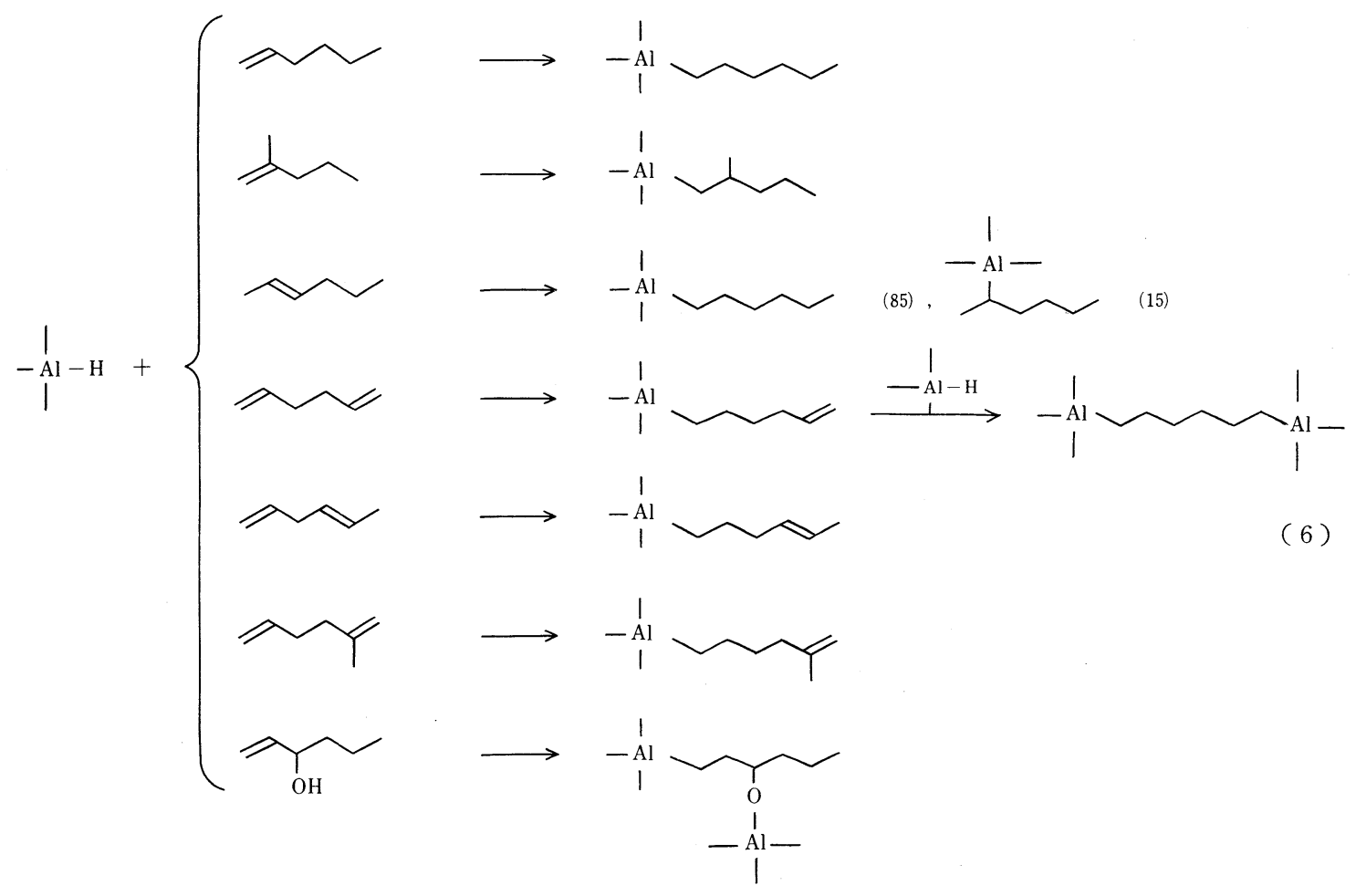

い 2 重結合のみ選択的に HAさせることができる。 HB でもポリェンに対して選択的反応を行らことが可能で あるが,このような目的のためにはジボランでなく、ジ シアミルボランや 9-BBN のような特別の試薬を用いな くてはならない2,3)。その点 $\mathrm{LiAlH}_{4}$ を用いて容易にポ リエンの選択的HAができ, テトラアルケニルアルミニ ウム化合物が得られることの合成的意義は大きいといえ よう。

共役ジエンの反応もモノハイドロアルミネーションが 優先し,アリル位に $\mathrm{Al}$ が付加した生成物が得られる7)。 しかし共役ジェンのHA を経由する合成反応はまだ未開 拓で, 今後の研究課題として残されている。

代表的オレフィンを例にとって以上の結果を式 6 亿示 した。

2.3. 触媒の不溶化 ${ }^{13)}$ 接触 HA反応で生成するア ルキルアルミニウムを触媒と分離することは難しい。HA を有機合成の手段として用いる立場からすると, 触媒を 分離することなく，そのまま次段階の反応を行うほう が手数がかからず好ましいともいえる。しかし次段階の 反応に拉いて，チタンあるいはジルコニウム化合物が残 存していると不都合な場合も考えられる。そのようなと き,シリカあるいはポリスチレンに担持させ不溶化した
チタン触媒 3，4，5 を用いてHA を行うと容易に触媒 をろ別することができ, さらに触媒の再使用も可能とな る。

$$
\left.\mathrm{SiO}_{2} \text { 害 } \mathrm{OH}+\mathrm{TiCl}_{4} \longrightarrow \mathrm{SiO}_{2} \text { 㓥O}\right)_{n} \mathrm{TiCl}_{4-\mathrm{n}}
$$

3

polystyrene 亲 $(0)-\mathrm{CH}_{2}-\left(\mathrm{O} \mathrm{Li}^{+}\right.$

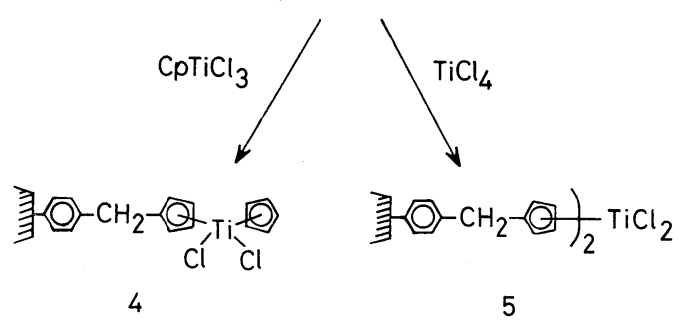

そのうえ,これら不溶化した触媒を用いるとHA反応 の選択性が均一系触媒を用いた場合と異なり, 以下述べ るような合成上有意義な応用が期待される結果が得られ ることがある。

$\alpha, \omega$-ジェンと $\mathrm{LiAlH}_{4}$ をル比 $4: 1$ で均一系触媒を 用いて反応させるとモノーおよびジーハイドロアルミネー 
ション生成物が約 $2.7: 1$ のモル比で得られる。同じ反 応を4あるいは 5 を用いて行うと, その比は約 $6: 1$ になりモノハイドロアルミネーションが優先する(式7)。 この原因としては原料のジェンにくらべて立体障害の大 きいモノハイドロアルミネーション生成物が担体中の活 性点までより拡散しにくいためと考えられる。
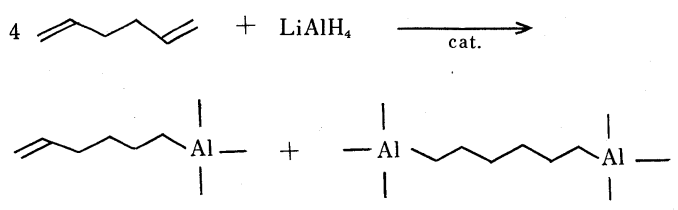

$$
\begin{array}{llll}
\mathrm{TiCl}_{4} & 2.7 & : & 1 \\
5 & 6 & : & 1
\end{array}
$$

\section{HA を経由する合成反応}

以上述べてきたようにオレフィンよりアルキルアルミ ニウムを容易に合成できるようになったが, 有機アルミ ニウムが有機合成に役立たなければHA反応の価值は少 ない。その点, すでに有機アルミニウムは有機リチウム,
マグネシウムあるいはホウ素化合物と同様に各種試薬と いろいろの反応を行うことが知られている ${ }^{1,14,15) 。 そ ~}$ れゆえ, HA 反応をこれら既知の反応性と組合わせるこ とによって有効な合成手段とすることができる。また有 機アルミニウム化合物の新しい反応性を開拓し，ょり一 層HA 反応を有効な合成手段とする努力もなされている。 ここではこれの結果をまとめる。

な㧍特別言及しない限り, 反応はアルミニウム水素化 物として $\mathrm{LiAlH}_{4}$, 溶媒として THFそして $\mathrm{TiCl}_{4}$ を触 媒として行っている。

3.1. オレフィンの水添 有機アルミニウム化合物 は容易に加水分解される。それゆえ，オレフィンの HA 後加水分解してアルカンに定量的に変換できる ${ }^{4)}$ 。この 方法は触媒を用いずにオレフィンを水添させる簡便な実 験室的方法になる。

特に興味深いのはジェン類の立体障害の小さい 2 重結 合のみを選択的に還元できることである ${ }^{5)}$ (表 2)。辻ら はこの方法を用いてブタジェンと酢酸のテロメリゼーシ ヨンによって得られる 1,7-オクタジェン-3-オール6の $\mathrm{C}_{7}$ オオレフィンのみを式 8 に示したよ5にして選択的 に還元し, マッタケオール7に導びいている ${ }^{16)} 。$

Table 2

Olefin

a) GLC yield, based on olefin 
HB を経由してオレフィンをアルカンにするには，有 機ボランは水や鈗酸に安定であるがカルボン酸と反応し てプロトノリシスされることを利用して行われる ${ }^{17) 。 ~}$

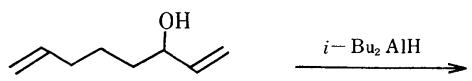

6<smiles>C=CCCCC(C=C)O[Mg]Br</smiles><smiles>CCCC</smiles><smiles>C=CC(O)CCCCC</smiles>

7

$\mathrm{LiAIR}_{4}$ とハロゲン化第二銅の反応によってもアルキ ルハライドが得られる ${ }^{20)}$ 。こ反応は NBSやNCSより 安価で入手容易なハロゲン化第二銅を用いて，非共役ジ エンよりアルケニルハライドを合成できる利点がある (表 2)。

反応は $\mathrm{LiAlR}_{4}$ と $\mathrm{CuX}_{2}$ との反応で, 直接の電子移動 あるいはアルキル銅中間体を経てアルキルラジカルが生 成し, ついでアルキルラジカルと $\mathrm{CuX}_{2}$ との間で配位子 移動が起こっていると考えられる（式 12 )。

$$
\mathrm{LiAlR}_{4}+8 \mathrm{CuX}_{2} \rightarrow 4 \mathrm{RX}+8 \mathrm{CuX}+\mathrm{AlX}_{3}+\mathrm{LiX}
$$

3. 2. アルキルハライドの合成 HA 後既知の反応 性を利用することによりオレフィンの末端炭素にハロゲ ンを導入することが容易にできる。オレフィンの HA後 $\mathrm{Br}_{2}$ あるいは $\mathrm{I}_{2}$ を作用させると 1 級アルキルハライドが 収率よく得られる ${ }^{4}$ 。 $\mathrm{Cl}_{2}$ との反応でアルキルクロライ ドを得るには，副反応をさけるため，反応後 THF を除 去し, ヘキサンーピリジン混合溶媒にかえて反応を行 ら必要がある。非共役ジェンのモノハイドロアルミネー ション後アルケニルハライドを得るには， $\mathrm{I}_{2}, \mathrm{NBS}, \mathrm{N}-$ CS を作用させて行われる ${ }^{5)}$ (表 2 )。

表 2 以外にたとえば式 $(9,10)$ のよち反応も容易に 行える。
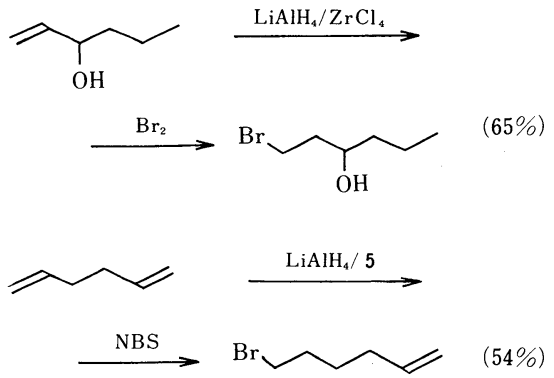

辻らはブタジェンとニトロエタンのテロマー8より天 然物 recifeiolide 9 を合成する際の工程にこの反応をと り入れている(式 11$)^{19)}$ 。<smiles>C=CCCC/C=C/CC(C)[N+](=O)[O-]</smiles><smiles>CCCCCCCCCCCC(=O)OC(C)C=CCCCCCCCI</smiles>

アルキルアルミニウムのハロゲノリシスが中性条件下 で進行するのに対し， $\mathrm{BR}_{3}$ のハロゲノリシスは強アルカ リ条件下で行う必要がある ${ }^{21)}$ ，しかも $\mathrm{I}_{2}$ との反応では, $\mathrm{BR}_{3}$ の 2 つのアルキル基しか反応に関与しない(式 13 )。

$$
\mathrm{BR}_{3}+2 \mathrm{I}_{2}+2 \mathrm{NaOH} \rightarrow 2 \mathrm{RI}+2 \mathrm{NaI}+\mathrm{RB}(\mathrm{OH})_{2}
$$

$\mathrm{BR}_{3}$ と $\mathrm{CuX}_{2}$ の反応によるアルキルハライドの合成も報 告されている ${ }^{22,23)}$ 。

3.3. アルコールの合成 $\mathrm{AlR}_{3}$ を空気酸化した後 加水分解して 1 級アルコールを得る方法は工業的アルコ 一ル合成法（Alfol 法）として知られている。この反応 と接触 HA反応を組合わせると実験室的アルコール合成 法となる ${ }^{6)}$ 。

酸化はアルミナート $\left(\mathrm{LiAlR}_{4}\right)$ よりアラン $\left(\mathrm{AlR}_{3}\right)$ を 経由して行ったほうが完全に進む。それゆえ反応は $\mathrm{AlH}_{3}$ を用いるHAにより，あるいはアート錯体を得た 後, 塩化アルミニウムを作用させて, トリアルキルアル ミニウムを合成してから行う（式 $14 ） 。$

$\mathrm{HB}$ 後アルカリ性 $\mathrm{H}_{2} \mathrm{O}_{2}$ で酸化してオレフィンをアル コールに導く方法が広く用いられているが3)，本反応も実 験室的アルコール合成法として充分利用できるであろう。
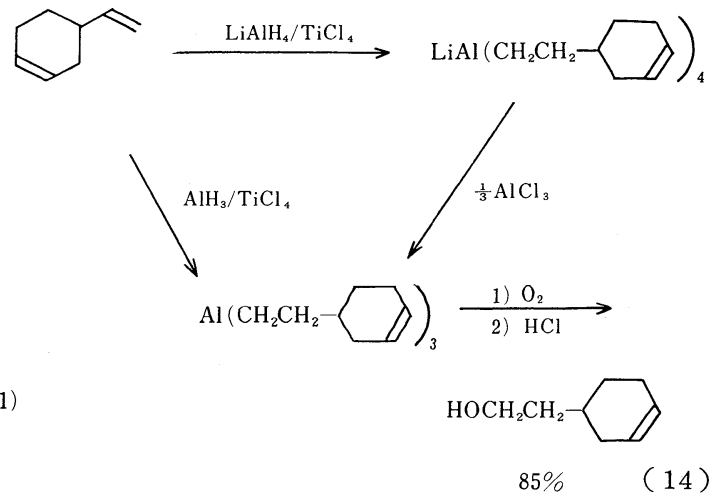
3.4. アセテートの合成 オレフィンの $\mathrm{HA}$ 後 $\mathrm{Pb}$ $(\mathrm{OAc})_{4}$ を作用させると一級アルキルアセテートが得ら れることが見い出されだ2)。反応は $\mathrm{LiAlR}_{4}$ を合成して 行うより, $\mathrm{LiAlH}_{4}$ と 2 当量のオレフィンの反応で $\mathrm{LiAlR}_{2} \mathrm{H}_{2}$ を合成して行ったほうが，オレフィン基準 でのアセテートの収率は高い（式 15 )。これは $\mathrm{LiAlR}_{4}$ の 2 つのアルキル基しか反応に関与しないからだと考え られる。結果を表 3 に示す。

$$
2 \mathrm{RCH}=\mathrm{CH}_{2}+\mathrm{LiAlH}_{4} \stackrel{\mathrm{TiCl}_{4}}{\longrightarrow} \stackrel{2 \mathrm{~Pb}(\mathrm{OAc})_{4}}{\longrightarrow}
$$

$$
2 \mathrm{RCH}_{2} \mathrm{CH}_{2} \mathrm{OAc}+2 \mathrm{~Pb}(\mathrm{OAc})_{2}
$$

$\mathrm{BR}_{3}$ と $\mathrm{Pb}(\mathrm{OAc})_{4}$ の反応でアルキルアセテートが得 られる ${ }^{25) 。 し か し ~} 2$ 級のアセテートがかなり副生し，才 レフィン基準での収率もあまり高くない。HB を経由す る一級アセテート合成法としては, Larockによる, HB

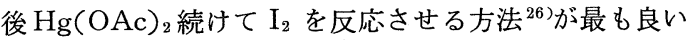
方法だと思われる（式 16 )。

$$
\begin{aligned}
& \mathrm{RCH}=\mathrm{CH}_{2} \stackrel{\frac{1}{3} \mathrm{BH}_{3}}{\longrightarrow} \stackrel{\mathrm{Hg}(\mathrm{OAc})_{2}}{\longrightarrow} \stackrel{\mathrm{I}_{2}}{\longrightarrow} \\
& \mathrm{RCH}_{2} \mathrm{CH}_{2} \mathrm{OAC}
\end{aligned}
$$

3.5. カップリング $\mathrm{BR}_{3}$ と $\mathrm{AgNO}_{3}$ の反応でカッ プリング物が得られる ${ }^{27)}$, 反応はアルキル銀を経て進行 していると考えられている。

大辻らはオレフィンの $\mathrm{HA}$ 後 $\mathrm{Cu}(\mathrm{OAc})_{2}$ を作用させ

\begin{tabular}{|c|c|c|}
\hline Olefin & Product & $\begin{array}{c}\text { Isolated } \\
\text { yield } \\
\text { (GLC) } \\
(\%)\end{array}$ \\
\hline 1-Hexene & Hexyl acetate & 58 \\
\hline 1-Octene & Octyl acetate & 51 \\
\hline $\begin{array}{l}\text { 4-Vinyl-1- } \\
\text { cyclohexene }\end{array}$ & $\begin{array}{l}2-(3-\text { Cyclohexenyl }) \\
\text { ethyl acetate }\end{array}$ & 64 \\
\hline $\begin{array}{l}\text { 2-Methyl-1, 5- } \\
\text { hexadiene }\end{array}$ & $\begin{array}{l}\text { 5-Methyl-5-hexenyl } \\
\text { acetate }\end{array}$ & $(65)$ \\
\hline 1,4-Hexadiene & 4-Hexenyl acetate & $(71)$ \\
\hline 1,5-Hexadiene & 1,6-Diacetoxyhexane & 59 \\
\hline 1,7-Octadiene & 1,8-Diacetoxyoctane & 60 \\
\hline
\end{tabular}
るとカップリング反応が進行することを見い出した ${ }^{28)}$ 。
Table 3 Anti-Markownikoff Esterification of Olefins.

しかし $\mathrm{LiAlRH}_{3}$ を経由して反応させているため，カッ プリング物 $(\mathrm{R}-\mathrm{R})$ の収率はオレフィン基準で $43 \sim 52$ \%にとどまり，さらに反応に用いる $\mathrm{Cu}(\mathrm{OAc})_{2}$ の量も オレフィンの 2 倍量を必要とした。

著者らは $\mathrm{LiAlR}_{4}$ を経由して反态を行うと, オレフ ィンと当量の $\mathrm{Cu}(\mathrm{OAc})_{2}$ を用いて表 4 に示すよ5に高 収率でカップリング物が得られることを明らかにした ${ }^{29)}$ 。 2 種類のオレフィンのカップリングでは入手し易いオレ フィンを過剩に用いることによりクロスカップリング生 成物の収率をあげることができる。

HB を経由するカップリング反応と比較すると, 本反 応では，(イ） $\mathrm{AgNO}_{3}$ に比し安価な $\mathrm{Cu}(\mathrm{OAc})_{2}$ を用 いることができる。(ロ $\mathrm{HB}$ 法では副生する 1-オレフ

Table 4 Yields and products of the coupling reaction.

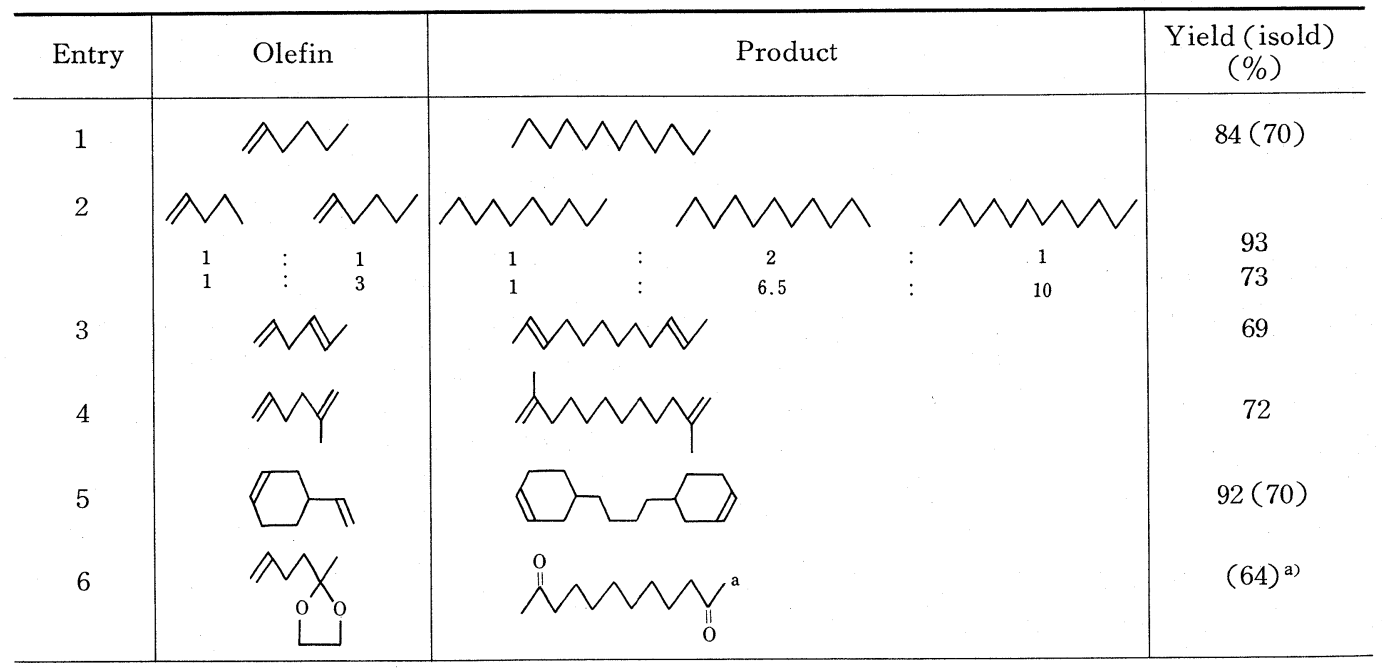

a) After hydrolysis of ketal with dil. $\mathrm{H}_{2} \mathrm{SO}_{4}$. 
インの $\beta$ 位でカップリングした生成物は副生しない。 （八） HB を経由して行らことは困難であると考えら れる。表 4 entry $3,4,5$ で示されるようなカップリン グ反応が容易にできる，等の利点がある。

しかし官能基を有するオレフィン類のカップリングに は HB 法のほらが適している場合が多いと考えられ，才 レフィンの種類により HA と HBを使いわけることが望 まれる。

上記カップリング反応を一酸化炭素雾囲気下で行う とケトン (RCOR) が $30 \sim 47 \%$ の収率で得られる ${ }^{29}$ 。 有機銅 $(\mathrm{I})$ 化合物へ $\mathrm{CO}$ が挿入してケトンが得られる ことが知られており ${ }^{30)}$ ，カップリング反応の中間体とし 有機銅が生成していることが強く示唆される。しかし有 機銅の生成機構や価数などの解明はなされていない。

3.6. 共役付加 有機銅化合物の $\alpha, \beta$-不飽和カル ボニル化合物への共役付加反応はよく知られている。3. 5. で述べたように $\mathrm{LiAlR}_{4}$ と $\mathrm{Cu}(\mathrm{OAc})_{2}$ の反応で中間 体として有機銅化合物の存在が考えられたので, $\mathrm{LiAlR}_{4}$ $と \alpha, \beta$-不飽和カルボニル化合物との反応を $\mathrm{Cu}(\mathrm{OAc})_{2}$ 存在下行った。その結果期待されたよ5に共役付加生 成物を得ることができた ${ }^{31}$ (表 5 )。反応は $\mathrm{LiAlR}_{4} よ り$ $\mathrm{LiAlR}_{2} \mathrm{H}_{2}$ を合成して行ったほうがオレフィン基準で の収率は良かった。この理由は有機銅の生成機構と関連 しているものと思われ今後の解明が待たれる（式 17 )。

$$
\begin{aligned}
& \mathrm{LiAlR}{ }_{2} \mathrm{H}_{2}+\mathrm{CH}_{2}=\mathrm{CH}-\underset{\mathrm{O}}{\mathrm{C}}-\mathrm{R}^{\prime} \stackrel{\mathrm{Cu}(\mathrm{OAc})_{2}}{\longrightarrow} \\
& 2 \mathrm{RCH}_{2} \mathrm{CH}_{2}-\underset{\mathrm{O}}{\mathrm{C}}-\mathrm{R}^{\prime} \quad\left(\mathrm{R}^{\prime}=\mathrm{H} \text { or } \mathrm{CH}_{3}\right)
\end{aligned}
$$

$\mathrm{BR}_{3}$ と $\alpha, \beta$ 不飽和ケトン拉よびアルデヒドの共役付 加反応はラジカル機構で起ることが知られている ${ }^{32,33) 。 ~}$ 実験操作はHAを経由する方法に比べ簡単容易である。 しかし $\mathrm{BR}_{3}$ の 1 個のアルキル基のみしか反応に関与しな いのでオレフィン基準での収率は低い。

3.7. カルボニル化合物への1,2-付加 有機リチウ ムやマグネシウム化合物のケトンやアルデヒドへの 1,2 付加反応は応用範囲の広い合成手段となっている。アル キルアルミニウム化合物も同様の反応をすることが知ら れているが，これまで種々のアルキルアルミニウム化合 物を簡単に合成することが困難であったこともあり，主 に反応機構的興味から研究はなされてきた ${ }^{34}$ 。ここの反応 をHA 反応と組合わせると合成的にも有用になる ${ }^{35}$ 。

反応はエーテル中 $\mathrm{Cp}_{2} \mathrm{TiCl}_{2}$ を触媒として $\mathrm{LiAlH}_{4}$ と オレフィンを反応させた後, 低温でケトンあるいはアル デヒドを滴下して行われる（式 18 )。
Table 5 Products of the Reaction of $\mathrm{LiAlR}_{2} \mathrm{H}_{2}$

\begin{tabular}{|c|c|c|}
\hline Olefin & Product & $\begin{array}{l}\text { Yield } \\
\text { (isold) } \\
(\%)\end{array}$ \\
\hline \multirow{2}{*}{ 1-Pentene } & Octanal & 57 \\
\hline & 2-Nonanone & 64 \\
\hline \multirow{2}{*}{ 1-Hexene } & Nonanal & $57(45)$ \\
\hline & 2-Decanone & $67(54)$ \\
\hline \multirow{2}{*}{ 1, 4-Hexadiene } & 7-Nonenal & $63(54)$ \\
\hline & 8-Decen-2-one & $65(58)$ \\
\hline \multirow{2}{*}{$\begin{array}{l}2-\text { Methyl-1, 5- } \\
\text { hexadiene }\end{array}$} & 8-Methyl-8-nonenal & 51 \\
\hline & $\begin{array}{l}\text { 9-Methyl-9-decen- } \\
\text { 2-one }\end{array}$ & 61 \\
\hline \multirow{2}{*}{$\begin{array}{l}\text { 4-Vinyl-1- } \\
\text { cyclohexene }\end{array}$} & $\begin{array}{l}5-(3-\text { Cyclohexenyl }) \\
\text { pentanal }\end{array}$ & 62 \\
\hline & $\begin{array}{l}6-(3-\text { Cyclohexenyl }) \\
\text { hexan-2-one }\end{array}$ & 71 \\
\hline 1,7-Octadiene & 2,15-Hexadecanedione & $(56)$ \\
\hline
\end{tabular}
with Acrolein or Methyl Vinyl Ketone.
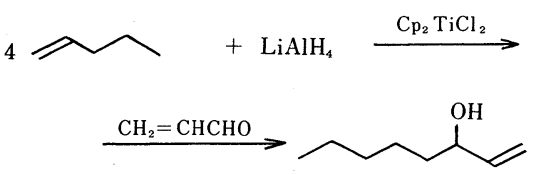

$\mathrm{LiAlR}_{4}$ のアルキル基のうち 1 個のみしか利用されな い反応ではあるが, オレフィンから直接対応するアルコ ールが得られる便利な方法である。なお，アルキルボラ ンはカルボニル基へ 1,2 付加しない。

3. 8. アリルハライド, プロパルギルハライド, およ びアレニルハライドとのカップリング $\mathrm{LiAlR}_{4}$ と種 々のアリルハライドとのカップリング反応が銅塩を触媒 とすると容易に起ることが見い出された ${ }^{36)}$ 。反応位位置 選択性高くアルリハライドの $\gamma$-位で反応する。また，特 に合成的に興味深いのはアリル位の八ロゲン以外の八ロ ゲンは反応に関与しないで残ることである（表 6)。

アリルハライドとの反応で位置選択性高く $\gamma$-位で反応 したことから，プロパルギルハライドとの反応でアレン が得られることが期待された。実際 $99 \%$ 以上の選択性

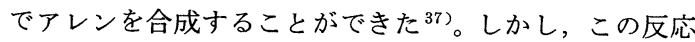
では $\mathrm{LiAlR}_{4}$ の 2 個のアルキル基しか利用されない上5 である。

さらに, アレニルブロマイドとも銅塩存在下容易に反 応して，1-アルキンをほぼ $100 \%$ の選択性で与えた ${ }^{38) 。 ~}$

これらの反応はオレフィンの炭素鎖を 3 個伸長した。 オレフィン，アレン，アセチレンを選択的に合成する簡 
Table 6 Coupling Products of Reactions of the Corresponding $\mathrm{LiAlR}_{4}$ with Allylic Chlorides.

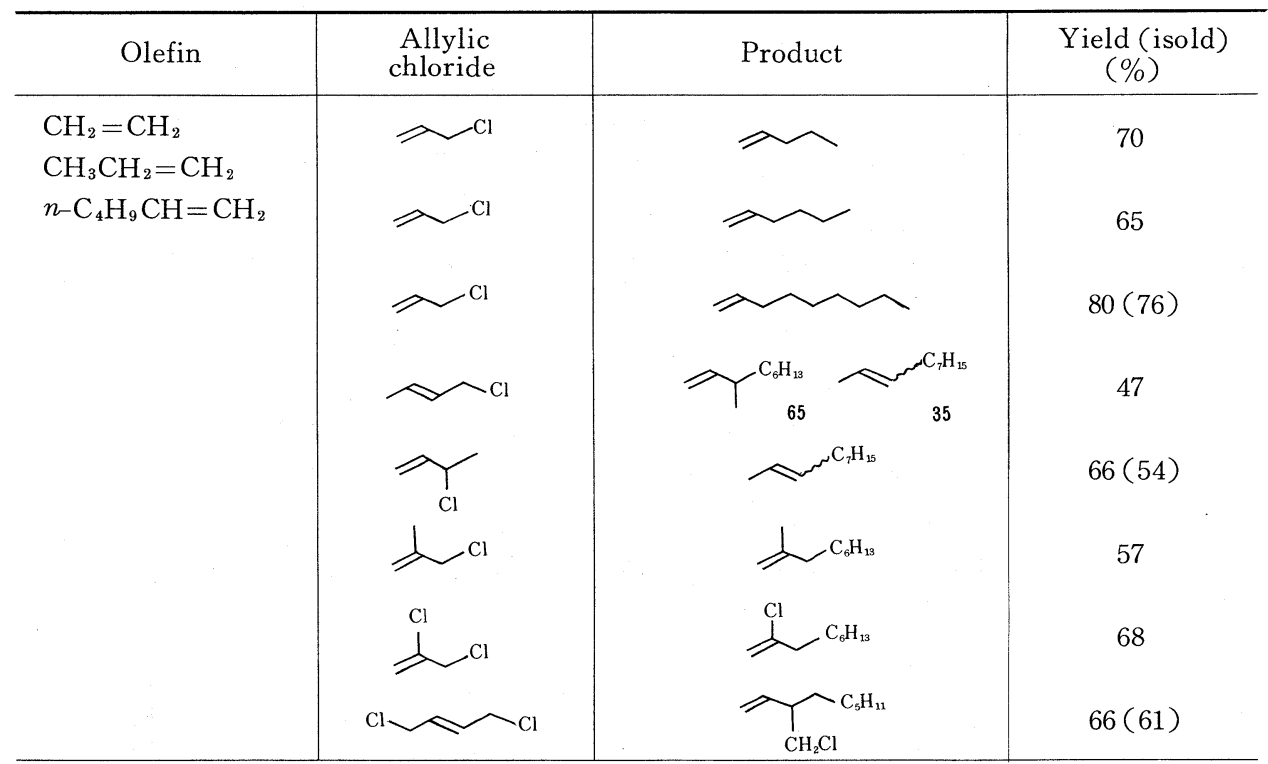

便な方法となろう（式 19）。

$$
\begin{gathered}
\mathrm{RCH}=\mathrm{CH}_{2} \stackrel{\mathrm{HA}}{\longrightarrow} \\
\begin{cases}\stackrel{\mathrm{CH}_{2}=\mathrm{CH}-\mathrm{CH}_{2} \mathrm{X} / \mathrm{CuCl}}{\longrightarrow} & \mathrm{RCH}_{2} \mathrm{CH}_{2} \mathrm{CH}_{2} \mathrm{CH}=\mathrm{CH}_{2} \\
\stackrel{\mathrm{CH} \equiv \mathrm{C}-\mathrm{CH}_{2} \mathrm{X} / \mathrm{CuCl}}{\longrightarrow} & \mathrm{RCH}_{2} \mathrm{CH}_{2} \mathrm{CH}=\mathrm{C}=\mathrm{CH}_{2} \\
\stackrel{\mathrm{CH}_{2}=\mathrm{C}=\mathrm{CHX} / \mathrm{CuCl}}{\longrightarrow} & \mathrm{RCH}_{2} \mathrm{CH}_{2} \mathrm{CH}_{2} \mathrm{C} \equiv \mathrm{CH}\end{cases}
\end{gathered}
$$

なお，これらの反応はいずれも有機銅化合物が中間体 として予想されているが, その解明は行っていない。

$\mathrm{HB}$ を経由する同様の反応に関しては鈴木らの研究が ある ${ }^{39)}$, 反応は銅ボラートにしてから行っている。こ の場合 $\mathrm{BR}_{3}$ の 1 個のアルキル基しか利用されない（式 20)。

$$
\begin{aligned}
& 3 \mathrm{RCH}=\mathrm{CH}_{2} \stackrel{\mathrm{BH}_{3}}{\longrightarrow} \stackrel{\mathrm{CH}_{3} \mathrm{Li}}{\longrightarrow} \stackrel{\mathrm{CuCl}}{\longrightarrow} \\
& {\left[\left(\mathrm{RCH}_{2} \mathrm{CH}_{2}\right)_{3} \mathrm{BCH}_{3}\right] \mathrm{Cu} \stackrel{\mathrm{CH}_{2}=\mathrm{CH}-\mathrm{CH}_{2} \mathrm{Cl}}{\longrightarrow}} \\
& \mathrm{RCH}_{2} \mathrm{CH}_{2} \mathrm{CH}_{2} \mathrm{CH}=\mathrm{CH}_{2}
\end{aligned}
$$

3.9. 酸無水物および酸クロライドとのカップリング $\mathrm{LiAlR}_{4}$ と酸無水物あるいは酸クロライドのカップリ ングが銅塩を触媒とすると容易に進行することが見い出 された ${ }^{40)}$ 。

たとえば，1-ヘキサンの HA 後, 無水プロピオン酸 つづいて触媒量の $\mathrm{CuCl}$ を加えると, 室温ですみやかに 反心して，3-ノナノンが $65 \%$ 收率 (1-ヘキセン基準)で
得られた（式 $21 ） 。$

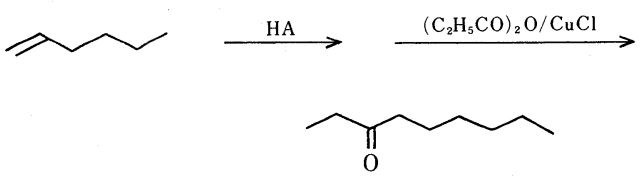

(21)

反応系に銅塩と当量の遊離基捕獲剤を加えると反応が 停止することから，反応はラジカル機構で進んでいると 考えられる。

$\mathrm{AlRCl}_{2}$ と酸クロライドの反応によるケトン合成法が, Adkinsらによって報告されている ${ }^{41)}$ 。 HAによって Al$\mathrm{RCl}_{2}$ を合成して上記反応を行ってもケトンが得られ る42)。しかし，エーテルの配位していない $\mathrm{AlRCl}_{2}$ を用 いないと反応は進行しないので, 反応はHAにより LiAl$\mathrm{R}_{4}$ を合成した後, 減圧下加熱してェーテルあるいは $\mathrm{THF}$ を除き, つづいてベンゼンや塩化エチレン中 $\mathrm{AlCl}_{3}$ を作用させ，エーテルの配位していない $\mathrm{AlRCl}_{2}$ を合成 して行わなくてはならない。

アルキルボラートと酸クロライドとの反応でもケトン が得られるが，ボラートのアルキル基の 1 個しか利用さ れない反応である ${ }^{43,44)}$ 。

3.10. 有機金属化合物の合成アアルキルアルミニ ウム基を種々の金属へトランスメタル化させることがで きる。それゆえ，HA を利用すると容易に種々の有機金 属化合物が合成でさると思われる。 
ホウ素へのトランスメタル化によるトリアルケニルボ ランの合成は次のようにして行われる ${ }^{45)}$ 。非共役ジェ ンのモノハイドロアルミネーション後, $\mathrm{BF}_{3}$. $\mathrm{OEt}_{2}$ を作 用させて，たとえば式 (22) で示されるようなトリア ルケニルボランが高収率で合成された。

3

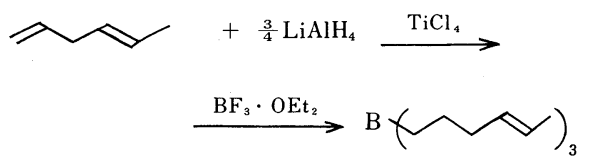

HB では合成できないトリアルケニルボランが容易に 得られることの合成的意義は大きい。

ホウ素以外の金属へのトランスメタル化; および，そ のようにして得られる有機金属化合物の特性を生かした 合成反応の展開が期待される。

\section{4. 他のハイドロメタレーション反応}

以上, オレフィン類の接触 HA に関してHB と比較し つつ述べてきた。ここでは, 適用範囲が広く有用な合成 手段となっている他のオレフィン類のハイドロメタレー ション反応について簡単にではあるが紹介したい。そのよ うな反応としては Schwarz らによるハイドロジルコネ ーション, および, 熊田一玉尾らによるハイドロシレー ションを経由する合成反応が挙げられよう。

ハイドロジルコネーションは $\mathrm{Cp}_{2} \mathrm{Zr}(\mathrm{H}) \mathrm{Cl}$ を試薬と する反応で, 非常に位置選択性の高い反応である。また, 他のハイドロメタレーション反応と異なり，1,3-ジェン との反応では式 (23) に示すように 1,2-付加して $r, \delta-$ 不飽和アルキルジルコニウム化合物を与えるなどの特色 をもち合成的応用が充分期待される ${ }^{46)}$ 。

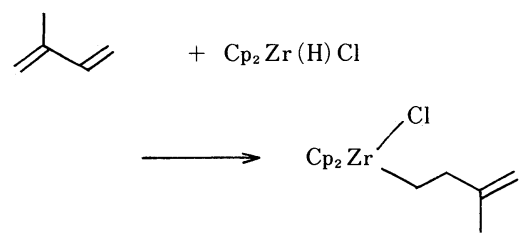

しかし, $\mathrm{Cp}_{2} \mathrm{Zr}(\mathrm{H}) \mathrm{Cl}$ は $\mathrm{BH}_{3}$ や $\mathrm{LiAlH}_{4}$ に比し入手 が困難であり，また分子量もかなり大きい(M.W. 257.7)。 さらにこの試楽のハイドライド源としてアルミニウム水

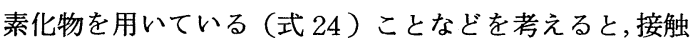
HA 反応で達成されるような反応については, ハイドロ ジルコネーションを経由して行うメリットはないと考 えられる。

$$
\mathrm{Cp}_{2} \mathrm{ZrCl}_{2}+\frac{1}{4} \mathrm{LiAlH}_{4} \longrightarrow \mathrm{Cp}_{2} \mathrm{Zr}<\underset{\mathrm{H}}{\mathrm{Cl}}
$$

ハイドロシレーションはよく知られた反応であるが， アルキルケイ素化合物の反応性が低いため，これまで有 機合成手段としては，ほとんど用いられなかった。

熊田, 玉尾らは最近 $\mathrm{HSiCl}_{3}$ を用いてのハイドロシレ ーション後, KFを作用させてペンタフルオロシリケート に変えると反応性が高くなることを見い出し オレフィ ン類のハイドロシレーションも有機合成手段として用い ることができることを明らかにした ${ }^{47)}$ (式 25 )。ケイ素 化合物はホウ素, アルミニウム, ジルコニウム化合物に 比べ酸素や水に安定であり, 次段階の反応を空気中で行 えるという特色をもっている。

$$
\begin{gathered}
\mathrm{RCH}=\mathrm{CH}_{2}+\mathrm{HSiCl}_{3} \stackrel{\text { cat. }}{\longrightarrow} \stackrel{\mathrm{KF}}{\longrightarrow} \\
\mathrm{K}_{2}\left[\mathrm{RCH}_{2} \mathrm{CH}_{2} \mathrm{SiF}_{5}\right]
\end{gathered}
$$

以上の 4つのハイドロメタレーション反応はそれぞれ特 色があり，オレフィンの種類や合成目的に応じて使いわ けていくことが望まれよう。

\section{5.おわりに}

標題テーマに関して, 私達の研究室でおこなった仕事 を中心にして紹介させていただいた。これらの研究は， 1976 年偶然にオレフィン類の接触HA を見い出したこと に端を発している。このHAの系はオレフィンーチタン 化合物一アルミニウム化合物という典型的な Ziegler 触 媒の系であり，そのような系であるにもかかわらずオレ フィンの重合が起らずHAが優先して起ったことは幸運 であったといえよ5。と同時にすでに相当多くの研究が なされてきたような系でも見方を変えれば，まだまだ興 味深い現象が見い出せるといら感をもつ。

この小文により，HA反応が有機合成面で活用される ことの一助となれば幸甚である。また著者の浅学のゆえ に誤り, 誤解等もあるかと思われるがご批判, ご教示い ただければ幸いである。

（昭和 54 年 9 月 5 日受理）

\section{文献}

1) K. Ziegler, "Organometallic Chemistry" (H. Zeiss ed.) Reinhold, New York, p 194, 1960

2) H.C. Brown, B.C. Subba Rao, J. Amer. Chem. Soc., 78, 5694 (1956) また Brown 自身の総説， 著書としては，たとえば H.C. Brown, "Organic Synthes via Boranes" John Wiley \& Sons, New York, 1975

3） H.Bを経由する合成に関する総説，著書は多いが, 
たとえば，鈴木 章“有機金属化合物を用いる 合成反応”（上） p 1，1974，(丸善）

4) F. Sato, S. Sato, M. Sato, M. Sato, J. Organomet. Chem., 122, C 25 (1976)

5) F.Sato, S.Sato, M. Sato, J. Organomet. Chem., 131, C 26 (1977)

6) F.Sato, S.Sato, H. Kodama, J. Organomet. Chem., 142, 71 (1977)

7) F.Sato, Fundamental Reserch in Homogeneous Catalysis" (Y. Ishii and M. Tsutsui eds.) vol 2, Plenum Press, New York, p 81, 1978)

8）佐藤史衛, 触媒, 21, 363 (1979)

9) E. Negishi, "New Application of Organometallic Reagents in Organic Synthesis" (D. Seyferth ed), Elsevier, Amsterdam, p 93, 1976

10) 内本喜一朗, 化学, 32, 728 (1977)

11) K. Isagawa, K. Tatsumi, Y. Otsuji, Chem. Lett., 1976, 1145

12) K. Isagawa, K. Tatsumi, Y. Otsuji, Chem. Lett., 1977, 1117

13) F. Sato, H. Ishikawa, Y. Takahashi, M. Miura, M. Sato, Tetrahedron Lett., 1979, 3745

14) A.N. Nesmeyanov, R.A. Sokolic, "The Organic Compounds of Borane, Aluminum, Gallium, Indium and Thallium"North-Holland, Amsterdam, p 437, 1967

15) H. Reinheckel, K. Haage, D. Jahnke, Organometal. Chem. Rev. A, 4, 47 (1969)

16) J. Tsuji, T.Mandai, Chem. Lett., 1977, 975

17) H.C. Brown, K. Murray, J. Am. Chem. Soc., 81, 4108 (1959)

18）佐藤史衛, 戸室康二, 石川弘明, 佐藤正雄, 日化 第 40 回秋季年会, $1 \mathrm{H} \mathrm{16,Chem.} \mathrm{Lett.,} \mathrm{1980,} 99$

19) I. Tsuji, T. Yamakawa, T. Mandai, Tetrahedron Lett., 1978, 565, T. Takahashi, S. Hashiguchi, K. Kasuga, J. Tsuji, J. Am. Chem. Soc., 100, 7424 (1978)

20) F.Sato, Y.Mori, M.Sato, Chem. Lett., 1978, 833

21) H.C. Brown, C.F.Lane, J. Am. Chem. Soc., 92, 6660 (1970)

22) C.F.Lane, J. Organomet. Chem., 31, 421(1971)

23) A. Arase, Y. Masuda, A. Suzuki, Bull. Chem. Soc. Jpn., 47, 2511 (1974)

24) F.Sato, Y. Mori, M.Sato, Tetrahedron Lett., 1979, 1405

25) Y.Masuda, A. Arase, Bull. Chem. Soc. Jpn., 51, 901 (1978)
26) R.C. Larock, J. Org. Chem., 39, 834 (1974)

27) H.C. Brown, C.H. Snyder, J. Am. Chem. Soc., 83, 1002 (1961)

28) K. Isagawa, M. Ohige, K. Tatsumi, Y. Otsuji, Chem. Lett., 1978, 1155

29) F.Sato, Y.Mori, M.Sato, Chem. Lett., 1978, 1337

30) J.Schwartz, Tetrahedron Lett., 1972, 2803

31) F.Sato, T. Oikawa, M.Sato, Chem. Lett., 1979, 167

32) A.Suzuki, A. Arase, H. Matsumoto, M. Itoh, H.C. Brown, M.M. Rogic, M.W. Rathke, J. Am. Chem. Soc., 89, 5709 (1967)

33) H.C. Brown, M.M. Rogic, M.W. Rathke, and G.W. Kabalaka, J. Am. Chem. Soc., 89, 5709 (1967)

34) E.C. Ashby, J.T. Laemmle, Chem. Rev., 75, 521 (1975)

35）佐藤史衛, 内田 博, 森 悦邦, 佐藤正雄, 日化 第 40 回秋季年会, $1 \mathrm{H} 17$

36) F.Sato, H. Kodama, M. Sato, J. Organomet. Chem., 157, C 30 (1978)

37) F.Sato, K. Oguro, M.Sato, Chem. Lett., 1978, 805

38) F.Sato, H. Kodama, M. Sato, Chem. Lett., 1978, 789

39) N. Miyaura, M. Itoh, A. Suzuki, Bull. Chem. Soc. Jpn., 50, 2199 (1977)

40) F. Sato, H. Kodama, Y. Tomuro, M. Sato, Chem. Lett., 1979, 623

41) H. Adkins, C. Scenley, J. Am. Chem. Soc., 73, 2854 (1951)

42) 佐藤史衛, 神保宗正, 佐藤正雄, 日化第 40 回秋 季年会, $1 \mathrm{H} 14$

43) E. Negishi, K.W. Chiu, T. Yoshida, J. Org. Chem., 40, 1676 (1975)

44) N. Miyaura, N. Sasaki, M. Itoh, A. Suzuki, Tetrahedron. Lett., 1977, 173

45) F.Sato, S.Haga, M.Sato, Chem. Lett., 1978, 999

46) J.Schwartz, "New Applications of Organometallic Reagents in Organic Synthesis", (D. Seyferth, ed.), Elsevier, Amsterdam, p 461, 1976

47) K. Tamao, T. Kakui, M. Kumada, J. Am. Chem. Soc., 100, 2268 (1978), J. Yoshida, K. Tamao, M. Takahashi, M. Kumada, Tetrahedron Lett., 1978, 2161, およびその引用文献 